\title{
Cross-taxon congruence in tree, bird and bat species distributions at a moderate spatial scale across four tropical forest types in the Philippines
}

\author{
Merlijn van Weerd • Helias A. Udo de Haes
}

Received: 29 March 2010/Accepted: 20 July 2010/Published online: 10 August 2010

(C) The Author(s) 2010. This article is published with open access at Springerlink.com

\begin{abstract}
Indicator species groups are often used as surrogates for overall biodiversity in conservation planning because inventories of multiple taxa are rare, especially in the tropics where most biodiversity is found. At coarse spatial scales most studies show congruence in the distribution of species richness and of endemic and threatened species of different species groups. At finer spatial scale levels however, cross-taxon congruence patterns are much more ambiguous. In this study we investigated cross-taxon patterns in the distribution of species richness of trees, birds and bats across four tropical forest types in a ca. $100 \times 35 \mathrm{~km}$ area in the Northern Sierra Madre region of Luzon Island, Philippines. A non-parametric species richness estimator (Chao1) was used to compensate for differential sample sizes, sample strategies and completeness of species richness assessments. We found positive but weak congruence in the distribution of all and endemic tree and bird and tree and bat species richness across the four forest types; strong positive congruence in the distribution of all and endemic bat and bird species richness and low or negative congruence in the distribution of globally threatened species between trees, birds and bats. We also found weak cross-taxon congruence in the complementarity of pairs of forest types in species richness between trees and birds and birds and bats but strong congruence in complementarity of forest pairs between trees and bats. This study provides further evidence that congruence in the distribution of different species groups is often ambiguous at fine to moderate spatial scales. Low or ambiguous cross-taxon congruence complicates the use of indicator species and species groups as a surrogate for biodiversity in general for local systematic conservation planning.
\end{abstract}

Keywords Conservation planning - Indicator species · Luzon · Northern Sierra Madre · Philippines $\cdot$ Species richness estimators $\cdot$ Surrogacy $\cdot$ Ultrabasic forest

M. van Weerd $(\bowtie) \cdot$ H. A. Udo de Haes

Institute of Environmental Sciences, Leiden University, PO Box 9518, 2300 RA Leiden,

The Netherlands

e-mail: merlijnvanweerd@yahoo.com

H. A. Udo de Haes

e-mail: udodehaes@cml.leidenuniv.nl 


\author{
Abbreviations \\ NSMNP Northern Sierra Madre Natural Park \\ DENR Department of Environment and Natural Resources \\ RP Republic of the Philippines \\ NIPAS National Integrated Protected Area System
}

\title{
Introduction
}

Information on the distribution and diversity of species is widely used as a basis for setting conservation priorities, selecting reserve sites and conservation management. In these practical applications of conservation biology, indicator species groups are often used as a surrogate for overall biodiversity (e.g. Williams et al. 1996; Mittermeier et al. 1998; Stattersfield et al. 1998; Mac Nally et al. 2002; Thiollay 2002). Many researchers have sought indicators that reliably predict species richness and distribution patterns in other species groups (e.g. Noss 1990; Pearson and Cassola 1992; Moore et al. 2003; Fleishman et al. 2005). In addition, researchers have tested whether patterns in the distribution of threatened or endemic species are good indicators of overall species richness within and across taxa (e.g. Kerr 1997; Bonn et al. 2002; Lamoreux et al. 2006). Identifying indicator species groups that serve as a surrogate for other species groups is tempting because it would greatly facilitate and economize the practices of setting conservation priorities and of monitoring biodiversity.

However, there is doubt whether a general pattern of cross-taxon congruence in the spatial distribution of different species groups exists (e.g. Gaston 1992; Balmford and Long 1995; Prendergast and Eversham 1997; Lawton et al. 1998; Lindenmayer 1999). In fact, little is known about cross-taxon congruence because comparative studies of multi-taxa species distributions remain rare, especially at local scales and even more so for the tropics (Wilson 2000). Studies that explore cross-taxon congruence use one or more measures from two different categories: measures of $\alpha$-diversity, i.e., species richness (Prendergast and Eversham 1997), number of endemic species and number of threatened species (Lamoreux et al. 2006); and measures of $\beta$-diversity, i.e., complementarity or similarity of community composition between two or more sites or habitat types ( $\mathrm{Su}$ et al. 2004).

At coarse spatial scales, $10,000 \mathrm{~km}^{2}$ and larger, most studies show there is concordance in the distribution of species richness between taxa, e.g. globally (Gaston 2000), in biodiversity hotspots (Myers et al. 2000), in WWF's ecoregions (Lamoreux et al. 2006), in the tropics in general (Balmford and Long 1995) and across $1^{\circ}$ latitude $\times 1^{\circ}$ longitude $(90-111 \times 111 \mathrm{~km})$ blocks in sub-Sahara Africa (Moore et al. 2003). At fine spatial scales, $100 \mathrm{~km}^{2}$ and smaller, cross-taxon congruence patterns are much more ambiguous sometimes showing very low (Prendergast et al. 1993; Howard et al. 1998) and sometimes high congruence (Lund and Rahbek 2002) often depending on whether taxa are ecologically similar or taxonomically nested (Negi and Gadgil 2002).

It is especially information on species distributions at fine and moderate spatial scales that is relevant as an input for systematic conservation planning, because these are the scale levels where practical decisions are made on future land use and protected area management (Margules and Pressey 2000; Theobald et al. 2000). Therefore, more studies on cross-taxon congruence are needed at these levels of scale, especially in the tropics where most biodiversity is found and conservation efforts are most urgently needed (Vane-Wright et al. 1991). 
In this study we compare congruencies in the distribution of woody plants (Spermatophytes with a diameter at breast height of at least $1 \mathrm{~cm}$, henceforth called trees), birds (Aves) and bats (Chiroptera) across four forest types in a tropical forest region in the Northern Sierra Madre, Luzon, the Philippines. At a global scale, the Philippines is a conservation priority combining exceptional levels of endemism with exceptional levels of threat (Myers et al. 2000; Brooks et al. 2002; Sodhi et al. 2004, 2010). Systematic conservation planning based on reliable biodiversity information is urgently needed to prevent species extinctions in the Philippines (Posa et al. 2008). Our objective is to analyze crosstaxon congruence patterns for a Philippine tropical forest region at a moderate spatial scale level (ca. $100 \times 35 \mathrm{~km}$ ) to assess whether the use of surrogate taxa for site-specific conservation planning would present difficulties in this conservation hotspot. An additional objective was to assess the relative conservation importance of the four forest types for the three species groups in the Northern Sierra Madre Natural Park (NSMNP).

\section{Materials and methods}

Study area

Field data were gathered in the Northern Sierra Madre Mountain Range which runs along the eastern part of northern Luzon with peaks reaching a maximum elevation of ca. 1,850 m. Nearly the entire Sierra Madre Mountain Range and the adjacent coastal waters of the Pacific Ocean in Isabela Province were declared a protected area in 1997: the

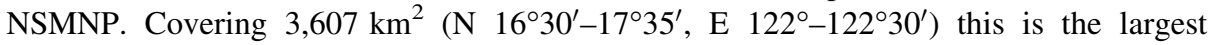
protected area of the Philippines The NSMNP represents the majority of habitats and bird species found on Luzon Island (Mallari and Jensen 1993; Poulsen 1995). The climate of the area is tropical and is dominated by the northeast (November-April) and southwest (MayOctober) monsoons with the driest period between February and May. Rainfall is strongly influenced by frequent typhoons and varies from an average of 1,649 $\mathrm{mm}$ (range 967-2,596 $\mathrm{mm}$ in the period 1975-2004) in Tuguegarao west of the mountains to an average of 3,534 mm (range 2,016-5,740 $\mathrm{mm}$ in 1975-2004) in Casiguran on the eastern side of the Sierra Madre south of the NSMNP (PAGASA 2005).

The Philippines is part of the Malesian floristic region (Collins et al. 1991). Several distinct forest types can be found in the NSMNP (Fig. 1) related to differences in soil characteristics, elevation and location. (1) Mangrove forest is found in shallow waters in secluded coastal bays and coves under saline conditions. Canopy height of mangrove forest in the NSMNP is $15 \mathrm{~m}$ at maximum and tree density (of trees $>1 \mathrm{~cm}$ diameter at breast height) in a 1 ha study plot was 3,769 individuals per ha (Garcia 2002a). (2) Lowland evergreen rain forest, numerically dominated by Dipterocarpaceae and therefore commonly called lowland dipterocarp forest (Collins et al. 1991), is found on well-drained clay loam and humus rich soils at elevations below $800 \mathrm{~m}$. In the NSMNP, the canopy layer of this forest type is at 30-35 m above ground with emergent trees up to $40 \mathrm{~m}$. Tree density in two study plots was 5,102-6,517 individuals per ha (Garcia 2002b, c). This forest type is commercially the most valuable for timber extraction. Most lowland dipterocarp forest in the Philippines has been logged (ESSC 1999) and the NSMNP was established to protect one of the last larger remnants in the country. (3) Ultrabasic (also called ultramafic) forest is found on soils which contain high concentrations of heavy metals and that are deficient in phosphorus, potassium and calcium (Proctor 2003). This forest type is poorly described and understood. Generally, shortage of nutrients and presence of toxic soils lead to stunted 


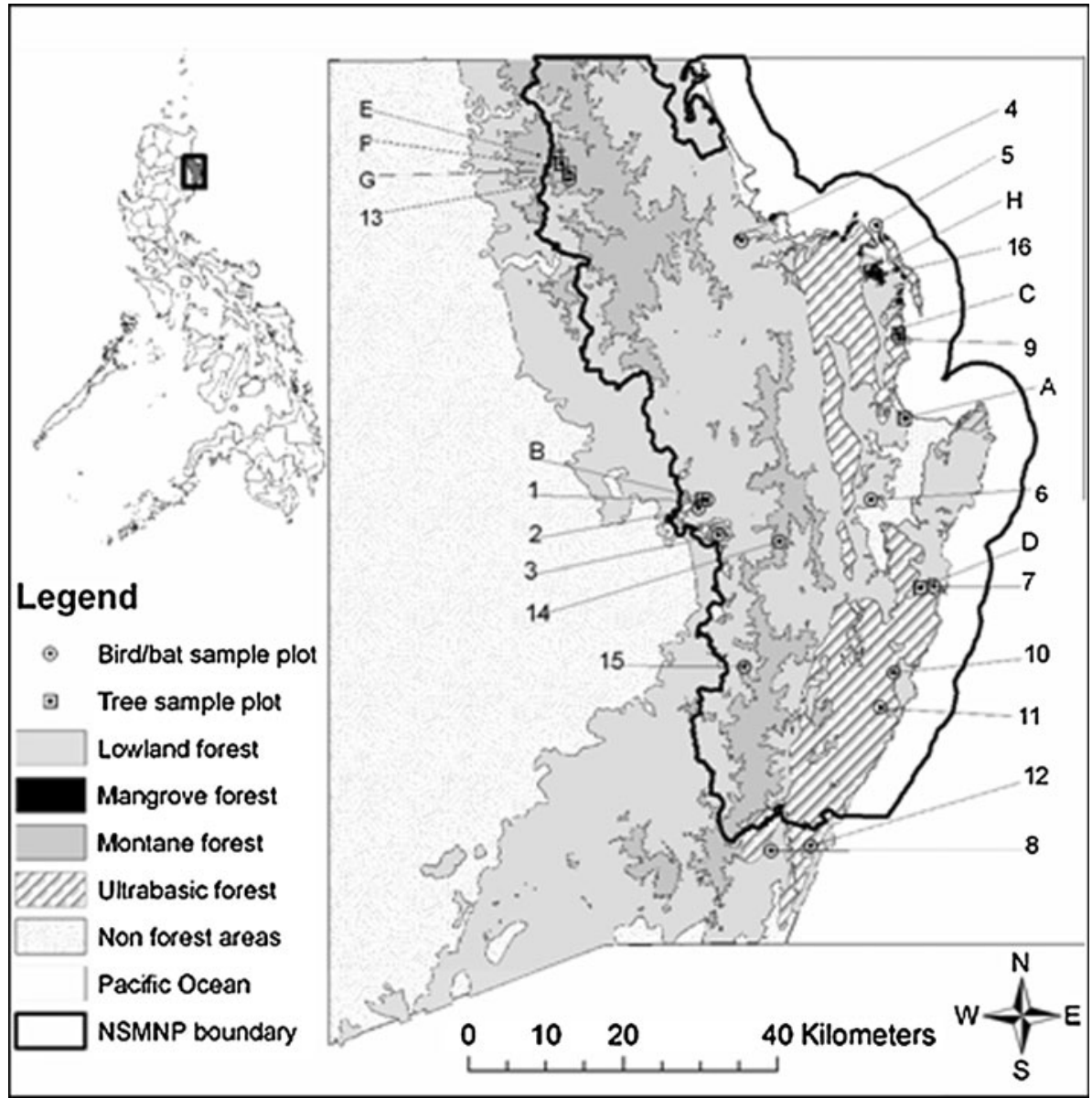

Fig. 1 Main forest types in the NSMNP and the locations of survey plots; letters refer to tree survey plots, numbers to bird and bat survey plots, codes as in Appendix 1. Cut-off in West and East is arbitrary, in North and South follows provincial boundaries. Inset shows location of NSMNP in Isabela Province in the Philippines. Map based on NAMRIA (1995), NORDECO and DENR (1998), Carranza et al. (1999), Andal et al. (2005), and ground validation by the first author

tree growth but there is great variation in species composition, species richness and forest structure between ultrabasic forests in different sites (Proctor 2003). In the NSMNP, ultrabasic forest is found on a large exposed ophiolite (uplifted oceanic crust) along the eastern margin of the park (Andal et al. 2005) at elevations from sea level up to $1,100 \mathrm{~m}$. At all elevations, canopy height is generally low at around $15 \mathrm{~m}$, but with great variation and at some locations emergent trees reach $40 \mathrm{~m}$. Tree densities were very high with 12,500-16,500 individuals per hectare in two study plots (Fortus and Garcia 2002a, b). (4) Montane forest (also called mossy forest as trees are often covered with bryophytes and filmy ferns) is generally found at elevations over $800 \mathrm{~m}$, but on smaller mountains and exposed ridges descends to as low as $500 \mathrm{~m}$. Dipterocarpaceae no longer occur here. Myrtaceae and Fagaceae are numerically the most common families. The canopy rarely exceeds $20 \mathrm{~m}$ and on exposed mountain ridges is lower than $5 \mathrm{~m}$ in height. Tree densities in this forest type were 5,740-8,684 individuals per ha in three study plots (Garcia 2002d). 
The NSMNP also has small areas of beach forest along the coast, freshwater swamp forest in areas that are flooded a large part of the year and forest on limestone soils (Co and Tan 1992). Data on these latter forest types were not available in sufficient detail and these forest types have not been included in the analyses here. In addition, several areas in the park have been converted to agricultural lands, grassland or shrub-land.

Data used in this paper were gathered within the framework of the Dutch funded NSMNP-Conservation Project (1996-2002) and the Cagayan Valley Program on Environment and Development (CVPED 2002-2006).

\section{Data collection}

Tree species diversity was determined by Hubert Garcia and co-workers (Garcia 2002a, b, c, d; Fortus and Garcia 2002a, b) during the period 1996-2002 using eight delineated plots in mangrove forest, lowland dipterocarp forest, ultrabasic forest and montane forest (Fig. 1, Appendix 1). Plot size was roughly based on the extent of the forest types within the park and varied from 0.04 ha (one plot), 0.25 ha (two plots), to 1 ha (five plots). All trees with a diameter at breast height over $1 \mathrm{~cm}$ were marked and identified using scientific and local names and species codes for morphospecies by trained teams of local fieldworkers and expert botanists. Specimen (fertile when possible) were collected of all species and stored in a herbarium at the local Isabela State University. Morphospecies were used consistently in the entire study for species that could not be identified. Voucher specimens were identified at the Philippine national herbarium, at the herbarium of the University of the Philippines' Institute of Biology, and by visiting experts. Nearly all specimens could be identified to genus level and $45 \%$ were identified to species level.

Bird and bat species diversity was determined by Van Weerd from 1999 to 2006 in survey plots of varying size (Fig. 1, Appendix 1) using a variety of methods to obtain the most complete species lists possible. Only data gathered in the four selected forest types have been used here and data were pooled for each survey plot. In mangrove forest one survey plot for birds and bats was established; in lowland dipterocarp forest, data were gathered in 10 survey plots for bats and eight for birds; in ultrabasic forest five plots for bats and four for birds were used and in montane forest four plots for both birds and bats were used. Within a survey plot fixed transect and point count localities were established to record birds, using both visual and vocal identification. Counts were conducted in the morning from 5.00 to 10.00 and late afternoon from 16.00 to 18.30 . Transects were generally $0.5 \mathrm{~km}$ long, had no fixed belt width, and followed hunting or wildlife trails. Point counts (15-60 min depending on new species detections, no fixed belt) were spaced to avoid double counting and placed at stratified random positions along trails. Mist nets were used to detect skulking and nocturnal birds and to survey bats. Mist nets were placed along creeks, along edges of small forest gaps and within forest interior at various heights. Mist net length was between 100 and $200 \mathrm{~m}$ (10-20 nets) and netting duration between two and 9 days. Species accumulation curves were constructed in field to determine stopping times. Surveys always lasted more than three full days with a maximum of 10 days. Bird species were identified following Kennedy et al. (2000). Bats were identified using Ingle and Heaney (1992).

\section{Data transformation}

In our study, surveys of trees, birds and bats varied in methodology, effort and coverage related to the abundance and detectability of these three species groups but as in any 
biodiversity survey the resulting observed species richness is an underrepresentation of the true species richness (Hortal et al. 2006). The uncertainty of the completeness of our species richness assessments complicates the comparison of total observed species richness between the three taxa across forest types. In such instants, an extrapolation or rarefaction technique has to be used to standardize richness data (Hortal et al. 2006). In our study two traditional methods to standardize species richness could not be used: a low number of distinct samples for the tree surveys limited the use of species-accumulation curves (DiazFrances and Soberon 2005) and because exact sample area was unknown for the bird and bat surveys, species-area curve extrapolation was also not possible (Koellner et al. 2004; Van Gemerden et al. 2005). However, recent years have seen the rapid development and testing of various non-parametric species richness estimation techniques that can be used to compensate for sampling biases when traditional extrapolation methods are inappropriate (Magurran 2004; Walther and Moore 2005). Species richness estimators try to estimate the total species richness of a defined biological community from an incomplete sample of this community (Walther and Moore 2005).

We choose to use the non-parametric abundance-based species richness estimator Chao1 to standardize our species richness data because it performs particularly well in comparisons when sample effort units differ (Hortal et al. 2006) or when sample sizes differ or consist of few or even single (sub)samples (Petersen and Meier 2003). Nonparametric species richness estimators are calculated with the aggregated observations of all samples of a given taxon in a sampling area and provide a lower bound estimate of true species richness (O'Hara 2005). The computer package EstimateS 8.0 (Colwell 2005) was used to calculate Chao1. We treated the aggregated observations of all species within one tree, bird or bat survey plot as one sample. The number of randomizations was set at 100 runs without replacement. The bias-corrected formula for Chao1 was used unless the coefficient of variation $(\mathrm{CV})$ of the abundance distribution was $>0.5$ in which case the larger Chaol of the classic or the bias-corrected formula was selected (Colwell 2005).

In addition, we used a related estimation technique in EstimateS 8.0 to calculate ChaoSorensen similarity indices between pairs of forest types for all three species groups (Chao et al. 2005; Colwell 2005). This method estimates the number of shared and unshared species in two samples from abundance data and calculates a Sorensen similarity index with these estimations (Chao et al. 2005). We then calculated complementarity scores in species richness between two forest types as 1-similarity. Complementarity between two forest types is 1 if two forest types do not share any species and 0 if they share all their species. Indices were calculated for pairs of forest types leading to six complementarity scores for each taxon.

\section{Cross-taxon congruence analysis}

Spearman's $\rho$ rank correlation was used to assess cross-taxon congruence across the four forest types for four measures: (1) total estimated species richness (Chao1); (2) the proportion endemic species of all identified species, (3) the proportion of globally threatened species of all identified species and (4) estimated complementarity of species richness between pairs of forest types. Threat status was based on the IUCN red list (IUCN 2008).

Species richness is intuitively meaningful and is widely used for comparisons of biodiversity. However, species richness alone is not a sufficient indicator of the conservation value of an area or forest type (Su et al. 2004) as it does not provide sufficient information on conservation priority. The presence of endemic and threatened species provides additional information on the global conservation importance of forest types as a habitat for the 
assessed taxa and is often used to set conservation priorities (e.g., Kerr 1997; Freitag and van Jaarsveld 1997; Myers et al. 2000; Bonn et al. 2002). We used the proportions of endemic and threatened species of all species as a relative measure of conservation importance of the forest types for the three species groups. To calculate these proportions, we divided the total number of observed endemic and threatened species by the total number of observed (not estimated) species. For trees this was done using the sub-set consisting only of species identified to species level (excluding morphospecies identified to genus level). These proportions represent conservative estimates of the true proportions of endemic and threatened species as especially unidentified and rare species (with a greater likelihood to escape detection) are likely to be endemic and threatened. Last, we assessed congruence in the uniqueness of forest types for the three species groups by comparing complementarity scores (Howard et al. 1998; Reyers et al. 2000).

\section{Results}

Sample data

In total 45,114 individual trees were recorded representing 735 species. Of these, 331 could be identified to species level (45\%). Of identified tree species, 182 were endemic to the Philippines (55\%). Of birds, 4,280 individuals were recorded, representing 174 species. Only resident species $(155, N=4,155)$ have been used in the data analyses to avoid bias caused by the presence/absence of migratory species in different periods of the year. Seventy-six bird species were endemic to the Philippines (49\% of resident species). A total of 852 bats were mist-netted representing 30 species. Eleven species (37\%) were endemic to the Philippines.

Uncorrected for sample effort, lowland dipterocarp forest had the largest species richness for birds and bats whereas ultrabasic forest was most species rich for trees (Table 1). Observed and estimated species richness (Chao1) was strongly correlated for trees (Spearman's $\rho=1.000, P<0.01$ ) and birds (Spearman's $\rho=1.000, P<0.01$ ) but weaker for bats (Spearman's $\rho=0.949, P=0.051$ ) which can be attributed to the high bat species richness estimation in montane forest compared to observed bat species richness there.

Estimated species richness, endemism, threatened species and complementarity

Among the four forest types compared, ultrabasic forest was the most species rich for trees (Chao1: 457 species; Table 1), followed by lowland dipterocarp forest (Chao1: 390 species) and montane forest (Chao1: 207 species). Mangrove forest was least species rich for trees (Chao1: 9 species), with no endemic or threatened species. The proportion of endemic trees $(52-59 \%$ of identified species in the lowland dipterocarp, montane and ultrabasic forest types) was lower than the $77 \%$ endemism reported for trees in the country as a whole (Myers et al. 2000) which can be attributed to the fact that a considerable portion of species in our study was not identified to species level. Lowland dipterocarp forest had the highest proportion of threatened species (11\%), followed by ultrabasic forest $(9 \%)$. No threatened tree species were found in montane and mangrove forest. The complementarity in tree species between forest types was remarkably high $(0.73-1)$ with most species unique to 
Table 1 The number of observed and estimated (Chao1) tree, bird and bat species, endemic species, threatened species and individuals in four forest types in the NSMNP on Luzon, the Philippines

\begin{tabular}{|c|c|c|c|c|c|c|c|c|}
\hline $\begin{array}{l}\text { Species } \\
\text { group/ } \\
\text { forest } \\
\text { type }\end{array}$ & $\begin{array}{l}\text { Observed } \\
\text { species } \\
\text { richness }\end{array}$ & $\begin{array}{l}\text { Estimated } \\
\text { species } \\
\text { richness } \\
(\text { Chao1) }\end{array}$ & Rank & $\begin{array}{l}\text { Endemic species } \\
(\% \text { of observed } \\
{\text { species richness })^{\mathrm{a}}}^{\mathrm{a}}\end{array}$ & $\begin{array}{l}\text { Rank } \\
\text { (based } \\
\text { on \%) }\end{array}$ & $\begin{array}{l}\text { Threatened } \\
\text { species }^{\mathrm{b}} \\
\text { (\% of observed } \\
\text { species richness) }^{\mathrm{a}}\end{array}$ & $\begin{array}{l}\text { Rank } \\
\text { (based } \\
\text { on \%) }\end{array}$ & $\begin{array}{l}\text { Observed } \\
\text { individuals }\end{array}$ \\
\hline \multicolumn{9}{|l|}{ Trees } \\
\hline MGF & 9 & 9 & 4 & $0(0)$ & 4 & $0(0)$ & 3 & 3,769 \\
\hline LDF & 293 & 390 & 2 & $110(59)$ & 1 & 21 (11) & 1 & 11,146 \\
\hline UBF & 409 & 457 & 1 & $76(52)$ & 3 & $13(9)$ & 2 & 29,579 \\
\hline MF & 179 & 207 & 3 & 37 (59) & 1 & $0(0)$ & 3 & 630 \\
\hline All & 735 & & & $182(55)$ & & $28(9)$ & & 45,114 \\
\hline \multicolumn{9}{|l|}{ Birds } \\
\hline MGF & 35 & 50 & 4 & 17 (49) & 4 & $0(0)$ & 4 & 265 \\
\hline LDF & 121 & 139 & 1 & $60(50)$ & 3 & $6(5)$ & 2 & 2,435 \\
\hline UBF & 75 & 83 & 3 & $45(60)$ & 2 & $3(4)$ & 3 & 680 \\
\hline MF & 76 & 90 & 2 & $49(65)$ & 1 & $5(7)$ & 1 & 775 \\
\hline All & 155 & & & $76(49)$ & & $11(7)$ & & 4,155 \\
\hline \multicolumn{9}{|l|}{ Bats } \\
\hline MGF & 7 & 8 & 4 & $2(29)$ & 4 & $1(14)$ & 3 & 173 \\
\hline LDF & 22 & 24 & 1 & $7(32)$ & 3 & $2(9)$ & 4 & 541 \\
\hline UBF & 11 & 11 & 3 & $4(36)$ & 1 & $2(18)$ & 1 & 81 \\
\hline MF & 11 & 19 & 2 & $4(36)$ & 1 & $2(18)$ & 1 & 57 \\
\hline All & 30 & & & $11(37)$ & & $5(17)$ & & 852 \\
\hline
\end{tabular}

$M G F$ mangrove forest, $L D F$ lowland dipterocarp forest, $U B F$ ultrabasic forest, $M F$ montane forest

a For trees, this is the proportion endemic and threatened species of all species identified to species level;

${ }^{b}$ Species classified as critically endangered, endangered or vulnerable on the IUCN red list (IUCN red list of threatened species 2008)

Table 2 The total number of observed tree, bird and bat species, shared species and complementarity between pairs of forest types in the NSMNP on Luzon, the Philippines

\begin{tabular}{|c|c|c|c|c|c|c|c|c|c|}
\hline \multirow[t]{2}{*}{ Forest type pairs } & \multicolumn{3}{|l|}{ Trees } & \multicolumn{3}{|l|}{ Birds } & \multicolumn{3}{|l|}{ Bats } \\
\hline & Tot S & Shared & $\mathrm{C}$ & Tot $S$ & Shared & $\mathrm{C}$ & Tot S & Shared & $\mathrm{C}$ \\
\hline LDF-UBF & 616 & 86 & 0.73 & 132 & 64 & 0.18 & 23 & 10 & 0.14 \\
\hline LDF-MF & 443 & 29 & 0.86 & 144 & 53 & 0.31 & 26 & 7 & 0.31 \\
\hline LDF-MGF & 302 & 0 & 1 & 124 & 32 & 0.26 & 25 & 4 & 0.49 \\
\hline UBF-MF & 529 & 59 & 0.76 & 110 & 41 & 0.26 & 17 & 5 & 0.37 \\
\hline UBF-MGF & 418 & 0 & 1 & 86 & 24 & 0.26 & 14 & 4 & 0.48 \\
\hline MF-MGF & 188 & 0 & 1 & 94 & 17 & 0.44 & 14 & 4 & 0.54 \\
\hline
\end{tabular}

Tot $S$ the total number of species in both forest types combined; Shared the number of shared species; $C$ complementarity score (1-Chao-Sorensen abundance-based similarity index); $L D F$ lowland dipterocarp forest, $U B F$ ultrabasic forest, $M F$ montane forest and $M G F$ mangrove forest

each type (Table 2). Although lowland dipterocarp forest and ultrabasic forest had the lowest complementarity in tree species $(0.73)$, together they had the highest combined tree species richness for any pair of two forest types (616 species). 
For birds, of the four forest types we compared in the NSMNP, lowland dipterocarp forest was most species rich (Chao1: 139 species) followed by montane forest (Chao1: 90 species). Ultrabasic forest (Chao1: 83 species) had an impoverished avifauna compared to lowland dipterocarp forest. Endemism was higher among birds found in ultrabasic forest (60\%) compared to lowland dipterocarp forest (50\%) but ultrabasic forest had, proportionally, less threatened species (4\%) than lowland dipterocarp forest (5\%). Montane forest had the highest proportions of endemic (64\%) and threatened (7\%) bird species. Mangrove forest had the lowest species richness (Chao1: 50 species), slightly lower endemism than the other forest types (49\%) and no threatened species. Complementarity in bird species was highest between montane and mangrove forest (0.44), the two forest types that were most strongly separated in terms of elevation. Lowland dipterocarp and montane forest combined had the highest bird species richness of any pair of forest types (144 species).

Similar to birds, for bats lowland dipterocarp forest was most species rich (Chao1: 24 species) followed by montane forest (Chao1: 19 species). Ultrabasic forest and mangrove forest were poorer than the other forest types in terms of bat species richness (Chao1: 11 species and 8 species respectively). Endemism did not vary much between the forest types (29-36\%) and was comparable with the proportion endemic bats of all bats in the Philippines (34\%) (Heaney et al. 1998). Montane forest and ultrabasic forest did have the highest proportions of threatened bats (18\%), lowland dipterocarp forest the lowest (9\%) although the number of threatened bat species was the same for all three forest types (two species). Complementarity was highest for montane forest and mangrove forest (0.54). Lowland dipterocarp and montane forest combined gave the highest bat species richness for a pair of forest types (26 species).

\section{Cross-taxon congruence}

Ultrabasic forest was the most diverse forest type in terms of tree species but for birds and bats this forest type ranked only third in a sequence of forest types in decreasing importance (Table 3). For all three taxa lowland dipterocarp forest was more species rich then montane forest, and montane forest more species rich then mangrove forest.

The sequence of decreasing proportions of endemic species and threatened species was different for each species group (Table 3). Lowland dipterocarp forest had highest tree

Table 3 The sequence of decreasing importance of four forest types for trees, birds and bats in terms of estimated species richness (Chao1), the proportion of endemic species and the proportion of threatened species in the NSMNP on Luzon, the Philippines

\begin{tabular}{|c|c|}
\hline Variable & Sequence of forest types in decreasing importance \\
\hline \multicolumn{2}{|c|}{ Estimated species richness (Chaol) } \\
\hline Trees & UBF (457)-LDF (390)-MF (207)-MGF (9) \\
\hline Birds & LDF (139)-MF (90)-UBF (83)-MGF (50) \\
\hline Bats & LDF (24)-MF (19)-UBF (11)-MGF (8) \\
\hline \multicolumn{2}{|c|}{ Proportion endemic species } \\
\hline Trees & LDF (59\%)-MF(59\%)-UBF (52\%)-MGF (0\%) \\
\hline Birds & MF (65\%)-UBF (60\%)-LDF (50\%)-MGF (49\%) \\
\hline Bats & UBF/MF (36\%)-LDF (32\%)-MGF (29\%) \\
\hline \multicolumn{2}{|c|}{ Proportion threatened species } \\
\hline Trees & LDF (11\%)-UBF (9\%)-MF/MGF (0\%) \\
\hline Birds & MF (7\%)-LDF (5\%)-UBF (4\%)-MGF (0\%) \\
\hline Bats & UBF/MF (18\%)-MGF (14\%)-LDF (9\%) \\
\hline
\end{tabular}

$L D F$ lowland dipterocarp forest, $U B F$ ultrabasic forest, $M F$ montane forest and $M G F$ mangrove forest 
Table 4 Cross-taxon congruence in the distribution of estimated species richness (Chao1), the proportions of endemic species and threatened species and complementarity between trees, birds and bats across four forest types in the NSMNP on Luzon, the Philippines

\begin{tabular}{lllll}
\hline $\begin{array}{l}\text { Species groups } \\
\text { compared }\end{array}$ & $\begin{array}{l}\text { Estimated species } \\
\text { richness }(\text { Chao1 }) \\
N=4\end{array}$ & $\begin{array}{l}\text { Proportion of } \\
\text { endemic species } \\
N=4\end{array}$ & $\begin{array}{l}\text { Proportion of } \\
\text { threatened species } \\
N=4\end{array}$ & $\begin{array}{l}\text { Complementarity } \\
\text { Trees-birds }\end{array}$ \\
\hline Trees-bats & $0.400(P=0.600)$ & $0.400(P=0.600)$ & $0.105(P=0.895)$ & $0.548(P=0.260)$ \\
Birds-bats & $1.000(P<0.01)$ & $0.949(P=0.051)$ & $0.211(P=0.789)$ & $0.577(P=0.231)$ \\
\hline
\end{tabular}

Spearman $\rho$ rank correlation coefficients

endemism and the highest proportion of threatened tree species, montane forest highest bird endemism and the highest proportion of threatened birds and ultrabasic forest and montane forest highest bat endemism and the highest proportions of threatened bats.

Cross-taxon congruence in estimated species richness across the four forest types was only weakly related between trees and birds $(\rho=0.400)$ and between trees and bats ( $\rho=0.400)$, but strongly between birds and bats $(\rho=1.000)$. Similarly, the proportion of endemic species in the four forest types was weakly correlated between trees and birds $(\rho=0.400)$, and trees and bats $(\rho=0.316)$, and stronger but not significantly between birds and bats $(\rho=0.949)$. The proportion of threatened species in the four forest types was very weakly correlated between trees and birds $(\rho=0.105)$ and between birds and bats $(\rho=0.211)$, and negatively between trees and bats $(\rho=-0.500)$. Complementarity of pairs of forest types finally was quite strongly positively correlated between trees and bats $(\rho=0.880)$ but weakly between trees and birds $(\rho=0.548)$ and birds and bats $(\rho=0.577)$ (Table 4).

\section{Discussion}

Our study suggests that there is positive but weak cross-taxon congruence in the distribution of tree species richness and bird and bat species richness at a moderate spatial scale $(100 \times 35 \mathrm{~km})$ across four distinct forest types in a tropical forest landscape in the Philippines. Ultrabasic forest is the most species rich forest type for trees but this forest type has lower bird and bat species richness compared to lowland dipterocarp forest and montane forest. Bird and bat species richness are much stronger correlated across the four forest types. Our results on ambiguous cross-taxon congruence in species richness at finer levels of spatial scales add to the reservation on this issue in other studies (Prendergast et al. 1993; Lawton et al. 1998; Part and Soderstrom 1999; Ricketts et al. 1999; Heino 2010) although Mac Nally et al. (2002) found strong similarities in the diversity of birds, mammals and trees in one hectare blocks in Australia. Species richness congruence between species groups is likely to be linked through functional relationships, for example by trophic interactions or ecological similarity (Negi and Gadgil 2002; Rodrigues and Brooks 2007) or structural complexity (Kissling et al. 2008).

Lowland dipterocarp forest, with its high canopy, complex structure and food resources for other taxa has the highest species richness of birds and bats. Ultrabasic forest in our study is idiosyncratic in its high tree species richness. The extreme richness of ultrabasic forest in the NSMNP in tree species is further supported by the findings of Co et al. (2004) who identified 335 tree species in a 16 ha plot in lowland dipterocarp forest in the NSMNP 
compared to the 409 tree species found in the total of two ha in our study in ultrabasic forest. Little is known about ultrabasic forests in the tropical Far East where some are very species poor and some exceptionally rich in plant species (Proctor 2003). Forest on ultrabasic soils in the Northern Sierra Madre clearly belongs to the latter category. The low bird species richness in ultrabasic forest in the NSMNP that we found is in concordance with avifaunal diversity studies in this forest type on other Southeast Asian islands (e.g. Poulsen and Lambert 2000) although ultrabasic forest on Borneo has several habitat specialist birds (Sheldon et al. 2009).

The decrease in tree species richness with elevation that we found in the NSMNP, and a floristic ecotone at about $800 \mathrm{~m}$ where dipterocarp dominated forest is replaced by oaklaurel forest, has been well described on wet tropical mountain areas (e.g. Ashton 2003). The lower bird species richness in montane forest in the NSMNP compared to lowland dipterocarp forest reflects the general higher species richness of Philippine birds at lower elevations: $61 \%$ of resident species are restricted to lowlands, $15 \%$ to montane areas over $1,000 \mathrm{~m}$ and the remainder of $24 \%$ occurs al all elevations (Kennedy et al. 2000). Bat diversity also decreases with elevation in other areas in the Philippines (Heaney 2001) although montane forest in our study was still relatively species rich for bats, likely as a result of the large elevation range of our study sites (500-1,750 m).

Positive but weak congruence between trees, and birds and bats is also found in the distribution of endemic species. Lowland dipterocarp forest has the highest proportion of endemic tree species, for birds and bats this forest type ranks third in endemism following ultrabasic and montane forest. Whereas mangrove forest is still a relatively important forest type for endemic birds and bats, no endemic trees are found there. At country level, congruence between Philippine plant and vertebrate endemism as a proportion of global species richness is 100\% (Myers et al. 2000), but our results show that there is much more heterogeneity in cross-taxon relations in endemic species richness at finer spatial scale levels.

The distribution of globally threatened species seems incongruent. Lowland dipterocarp forest has the highest relative occurrence of threatened tree species, whereas for birds and bats montane forest is the most important forest type in this respect. Within the two survey plots in lowland dipterocarp forest, nine endemic dipterocarp tree species were recorded that are listed as Critically Endangered (Table 5), of these only two also occur in ultrabasic forest. Lowland dipterocarp and ultrabasic forest have comparable numbers of threatened tree species within the lower threat categories. In mangrove forest and montane forest no tree species listed as globally threatened were recorded. No globally threatened birds were recorded in mangrove forest either but montane forest is an important forest type for threatened birds. This is largely due to the fact that endemic montane species have small ranges and are thus more vulnerable to even small changes in montane forest cover (Brooks et al. 1999) and as a result qualify easier as threatened under the area change criteria of the IUCN Red List. Montane forest in the NSMNP has several enigmatic bird species, among which the Critically Endangered Philippine Eagle Pithecophaga jefferyi, the conservation icon of the Philippines. In this study, only one globally threatened species was recorded in mangrove forest, the Endangered fruit bat Acerodon jubatus. Cross-taxon congruence between the proportions of threatened trees and bats across the four forest types correlated negatively. It must be noted however that trees have not been completely assessed for the IUCN Red List, possibly explaining the lack of tree species classified as threatened in montane forest.

In contrast to studies in Uganda (Howard et al. 1998) and Denmark (Lund and Rahbek 2002), we also found weak cross-taxon congruence in complementarity of species richness 
Table 5 Presence (X) of globally threatened tree, bird and bat species (IUCN 2008) in survey plots in four forest types in the NSMNP on Luzon, the Philippines

\begin{tabular}{lllll}
\hline Forest type species & $\begin{array}{l}\text { Mangrove } \\
\text { forest }\end{array}$ & $\begin{array}{l}\text { Lowland dipterocarp } \\
\text { forest }\end{array}$ & $\begin{array}{l}\text { Ultrabasic } \\
\text { forest }\end{array}$ & $\begin{array}{l}\text { Montane } \\
\text { forest }\end{array}$ \\
\hline
\end{tabular}

Trees

Critically endangered

Dipterocarpus validus $\quad \mathrm{X}$

Dipterocarpus grandiflorus $\quad \mathrm{X}$

Hopea acuminata X X

Hopea malibato $\quad \mathrm{X}$

Shorea contorta X

Shorea guiso $\quad \mathrm{X}$

Shorea negrosensis $\quad \mathrm{X}$

Shorea palosapis $\quad \mathrm{X}$

Shorea polysperma X X X

Endangered

Vatica mangachapoi

$\mathrm{X}$

Vulnerable

Mangifera altissima

Dillenia philippinensis

X

$\mathrm{X}$

X

Dillenia reifferscheidtia

$\mathrm{X}$

Macaranga bicolor

X

Macaranga grandifolia

X

Lithocarpus ovalis

X

Gonystylus macrophyllus

X

Litsea leytensis

$\mathrm{X}$

Adenanthera intermedia

$\mathrm{X}$

Afzelia rhomboidea

X

Cynometra cfinaequifolia

X

Pterocarpus indicus

Artocarpus blancoi

Artocarpus rubrovenus

Myristica frugifera

Ardisia squamulosa

Aquilaria cumingiana

Diplodiscus paniculatus

Birds

Critically endangered

Oriolus isabellae

X

Pithecophaga jefferyi

Vulnerable

Spizaetus philippensis

X

X

Ducula carola

$\mathrm{X}$

Bubo philippensis

X

$\mathrm{X}$

$\mathrm{X}$

X

X

X

Prioniturus luconensis

Ceyx melanurus

X 
Table 5 continued

\begin{tabular}{|c|c|c|c|c|}
\hline Forest type species & $\begin{array}{l}\text { Mangrove } \\
\text { forest }\end{array}$ & $\begin{array}{l}\text { Lowland dipterocarp } \\
\text { forest }\end{array}$ & $\begin{array}{l}\text { Ultrabasic } \\
\text { forest }\end{array}$ & $\begin{array}{l}\text { Montane } \\
\text { forest }\end{array}$ \\
\hline Pitta kochi & & & & $\mathrm{X}$ \\
\hline Rhyacornis bicolor & & & & $\mathrm{X}$ \\
\hline Hypothymis coelestis & & & $\mathrm{X}$ & \\
\hline Erythrura viridifacies & & $\mathrm{X}$ & & \\
\hline Bats & & & & \\
\hline \multicolumn{5}{|l|}{ Endangered } \\
\hline Pteropus leucopterus & & $\mathrm{X}$ & $\mathrm{X}$ & \\
\hline Acerodon jubatus & $\mathrm{X}$ & & & \\
\hline \multicolumn{5}{|l|}{ Vulnerable } \\
\hline Haplonycteris fischeri & & $\mathrm{X}$ & $\mathrm{X}$ & \\
\hline Otopteropus cartilagonodus & & & & $\mathrm{X}$ \\
\hline Rhinolophus subrufus & & & & $\mathrm{X}$ \\
\hline
\end{tabular}

in pairs of forest types for trees and birds and birds and bats. Only trees and bats showed a strong relation between complementarity scores for forest type pairs. In this respect, our results are more concordant with studies at a fine spatial scale in Cameroon (Lawton et al. 1998), where there is low congruence between taxa in changes in species richness along a disturbance gradient in a mosaic of forest habitats. Posa and Sodhi (2006) found a similar incongruence in the response of forest birds and butterflies to forest disturbance in lowland tropical forest in Subic Bay, also on Luzon in the Philippines.

\section{Conservation implications}

Our results indicate considerable heterogeneity in the distribution of species richness, endemism and globally threatened species of different species groups in different forest types in the Philippines. This has implications for the management of protected areas. The Philippines is still in the process of establishing a new protected areas system following the adoption of the National Integrated Protected Area System (NIPAS) law in 1991. As scientists are only just beginning to survey and map the distribution of many lesser studied taxa in the Philippines, there is a large risk that data on only one or a few taxa will be used as a basis for decisions on the location of new protected areas and the zoning of existing ones. Only information on the distribution of Philippine birds is comprehensive and synthesized (Mallari et al. 2001). Efforts are now increasingly being exerted to collate information on other taxa as well (Ong et al. 2002) but information on for example the presence and distribution of plant species, including trees, is lacking for most protected areas in the Philippines (Langenberger et al. 2006).

The NIPAS law allows freedom for protected area management to establish user zones within parks (RP 1991; DENR 1992). Park management has to decide on the allocation of natural resource use by local communities and other stakeholders (DENR 1992). Within the NSMNP there is a risk that the ultrabasic rock formation that underlies the tree speciesrich ultrabasic forest will be allotted to mining activities. With the revitalization and stimulation of the mining industry in the Philippines by current government (RP 2004), mining companies can explore and claim areas with high mineral extraction potential even 
in protected areas. The ultrabasic Isabela oliophite within the NSMNP has a proven high potential for nickel extraction (Carranza et al. 1999). On the basis of bird distribution data alone one could argue that economic gains from mining may overrule the limited biodiversity value of this forest type compared to other forest types. As this study shows, that would mean that an area exceptionally rich in tree species would lose its protected status. We therefore argue caution in using limited biodiversity data as a basis for protected area management decisions and join with other authors (Prendergast and Eversham 1997; Caro and O'Doherty 1999; Lindenmayer et al. 2002; Hess et al. 2006) to caution against the use of indicator taxa as surrogates for biodiversity at fine levels of spatial scale.

Acknowledgements The data on which this study is based were gathered during field work over many years by a large number of people. The authors thank Dominic Rodriguez, Bernard Tarun, Jessie Guerrero and community counterparts for invaluable field assistance during the bird and bat surveys. Hubert Garcia and the NSMNP-CP flora study team with a large number of community counterparts were responsible for documenting and describing tree diversity in the various habitats of the NSMNP. All of the tree diversity studies, and most of the bird and bat surveys were conducted under the auspices of the NSMNP-Conservation Project (1996-2002) which was implemented by PLAN International with funding by the Dutch government. Further studies (2002-2006) by the first author were made possible through financial assistance by Leiden University and through a RSPB small grant. Logistical support was provided by the Cagayan Valley Program on Environment and Development (CVPED), the academic partnership of Isabela State University and the Institute of Environmental Sciences of Leiden University. Wil Tamis and Denyse Snelder commented on earlier drafts of this manuscript. One anonymous referee and George Hess provided extensive comments on an earlier submission of this manuscript in a different form. We are also grateful to one anonymous referee for helpful comments on the manuscript in its present form.

Open Access This article is distributed under the terms of the Creative Commons Attribution Noncommercial License which permits any noncommercial use, distribution, and reproduction in any medium, provided the original author(s) and source are credited.

\section{Appendix 1}

See Table 6.

Table 6 The location and characteristics of tree, bird and bat survey sites in the NSMNP on Luzon, the Philippines with a summary of survey effort

\begin{tabular}{|c|c|c|c|c|c|c|c|c|c|}
\hline \multirow[t]{2}{*}{$\operatorname{Code}^{\mathrm{a}}$} & \multirow[t]{2}{*}{ Locality } & \multirow{2}{*}{$\begin{array}{l}\text { Forest } \\
\text { type }\end{array}$} & \multirow[t]{2}{*}{ Elevation $^{\mathrm{b}}$} & \multirow[t]{2}{*}{ Co-ordinates } & \multirow{2}{*}{$\begin{array}{l}\text { Trees } \\
\text { Plot } \\
\text { area } \\
\text { (ha) }\end{array}$} & \multicolumn{2}{|l|}{ Birds } & \multicolumn{2}{|c|}{ Birds/bats } \\
\hline & & & & & & $\begin{array}{l}\text { Transect } \\
\text { length }(\mathrm{km})\end{array}$ & $\begin{array}{l}\text { No of } \\
\text { point } \\
\text { counts }\end{array}$ & $\begin{array}{l}\text { Mist } \\
\text { net } \\
\text { days }\end{array}$ & $\begin{array}{l}\text { Mist net } \\
\text { nights }\end{array}$ \\
\hline
\end{tabular}

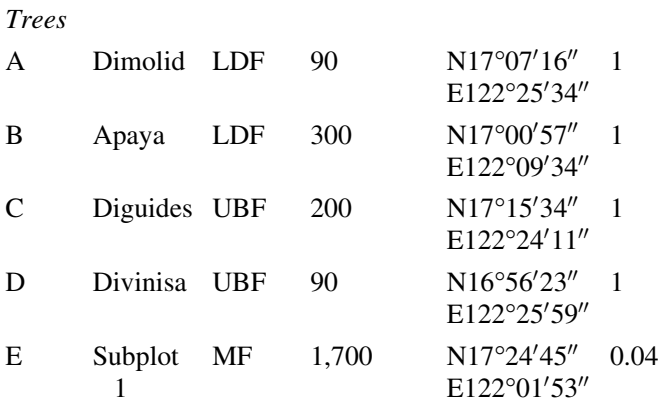


Table 6 continued

\begin{tabular}{|c|c|c|c|c|c|c|c|c|c|}
\hline \multirow[t]{2}{*}{$\operatorname{Code}^{\mathrm{a}}$} & \multirow[t]{2}{*}{ Locality } & \multirow{2}{*}{$\begin{array}{l}\text { Forest } \\
\text { type }\end{array}$} & \multirow[t]{2}{*}{ Elevation $^{\mathrm{b}}$} & \multirow[t]{2}{*}{ Co-ordinates } & \multirow{2}{*}{$\begin{array}{l}\text { Trees } \\
\text { Plot } \\
\text { area } \\
\text { (ha) }\end{array}$} & \multicolumn{2}{|l|}{ Birds } & \multicolumn{2}{|c|}{ Birds/bats } \\
\hline & & & & & & $\begin{array}{l}\text { Transect } \\
\text { length } \\
(\mathrm{km})\end{array}$ & $\begin{array}{l}\text { No of } \\
\text { point } \\
\text { counts }\end{array}$ & $\begin{array}{l}\text { Mist } \\
\text { net } \\
\text { days }\end{array}$ & $\begin{array}{l}\text { Mist } \\
\text { net } \\
\text { nights }\end{array}$ \\
\hline $\mathrm{F}$ & Subplot 2 & MF & 1,500 & $\begin{array}{l}\mathrm{N} 17^{\circ} 24^{\prime} 57^{\prime \prime} \\
\mathrm{E} 122^{\circ} 01^{\prime} 30^{\prime \prime}\end{array}$ & 0.25 & & & & \\
\hline G & Subplot 3 & MF & 1,450 & $\begin{array}{l}\mathrm{N} 17^{\circ} 25^{\prime} 50^{\prime \prime} \\
\mathrm{E} 122^{\circ} 00^{\prime} 35^{\prime \prime}\end{array}$ & 0.25 & & & & \\
\hline $\mathrm{H}$ & Dimasalansan & MGF & 0 & $\begin{array}{l}\mathrm{N} 17^{\circ} 18^{\prime} 27^{\prime \prime} \\
\mathrm{E} 122^{\circ} 23^{\prime} 10^{\prime \prime}\end{array}$ & 1 & & & & \\
\hline \multicolumn{10}{|c|}{ Birds/bats } \\
\hline 1 & Apaya & LDF & $250-350$ & $\begin{array}{l}\mathrm{N} 17^{\circ} 01^{\prime} 46^{\prime \prime} \\
\mathrm{E} 122^{\circ} 11^{\prime} 34^{\prime \prime}\end{array}$ & & 4.1 & & 5 & 5 \\
\hline 2 & Ambabok & LDF & $200-260$ & $\begin{array}{l}\mathrm{N} 17^{\circ} 01^{\prime} 28^{\prime \prime} \\
\mathrm{E} 122^{\circ} 10^{\prime} 46^{\prime \prime}\end{array}$ & & 3.2 & 4 & 9 & 9 \\
\hline 3 & Pagsungayan & $\mathrm{LDF}$ & $300-350$ & $\begin{array}{l}\mathrm{N} 16^{\circ} 59^{\prime} \\
\mathrm{E} 122^{\circ} 11^{\prime}\end{array}$ & & & & 4 & 4 \\
\hline 4 & Dicaruyan & LDF & 100 & $\begin{array}{l}\mathrm{N} 17^{\circ} 20^{\prime} 06^{\prime \prime} \\
\mathrm{E} 122^{\circ} 13^{\prime} 33^{\prime \prime}\end{array}$ & & & 5 & 4 & 3 \\
\hline 5 & Honeymoon & LDF & $0-40$ & $\begin{array}{l}\mathrm{N} 17^{\circ} 20^{\prime} 43^{\prime \prime} \\
\mathrm{E} 122^{\circ} 23^{\prime} 28^{\prime \prime}\end{array}$ & & 1.45 & & 3 & 3 \\
\hline 6 & Villa Robles & LDF & $100-200$ & $\begin{array}{l}\mathrm{N} 17^{\circ} 02^{\prime} 15^{\prime \prime} \\
\mathrm{E} 122^{\circ} 23^{\prime} 22^{\prime \prime}\end{array}$ & & 2.5 & & 4 & 3 \\
\hline (1) & Apaya2 & LDF & $250-350$ & $\begin{array}{l}\mathrm{N} 17^{\circ} 01^{\prime} 46^{\prime \prime} \\
\mathrm{E} 122^{\circ} 11^{\prime} 34^{\prime \prime}\end{array}$ & & & 10 & 2 & 3 \\
\hline (2) & Ambabok2 & LDF & $200-260$ & $\begin{array}{l}\mathrm{N} 17^{\circ} 01^{\prime} 28^{\prime \prime} \\
\mathrm{E} 122^{\circ} 10^{\prime} 46^{\prime \prime}\end{array}$ & & & 15 & 2 & 3 \\
\hline 7 & Magsinaraw $^{c}$ & LDF & 50 & $\begin{array}{l}\text { N16 } 16^{\circ} 56^{\prime} 28^{\prime \prime} \\
\text { E122 } 22^{\circ} 27^{\prime} 13^{\prime \prime}\end{array}$ & & & & & 2 \\
\hline 8 & Dicadican $^{c}$ & LDF & 575 & $\begin{array}{l}\text { N16 } 36^{\circ} 8^{\prime} 08^{\prime \prime} \\
\text { E122 } \\
\\
15^{\prime} 08^{\prime \prime}\end{array}$ & & & & & 3 \\
\hline 9 & Diguides & UBF & $20-250$ & $\begin{array}{l}\mathrm{N} 17^{\circ} 12^{\prime} 33^{\prime \prime} \\
\mathrm{E} 122^{\circ} 25^{\prime} 14^{\prime \prime}\end{array}$ & & 3.0 & & 4 & 3 \\
\hline 10 & Pangden & $\mathrm{UBF}$ & 50 & $\begin{array}{l}\text { N16 } 46^{\circ} 49^{\prime} 57^{\prime \prime} \\
\text { E122 } 22^{\circ} 25^{\prime} 05^{\prime \prime}\end{array}$ & & 2.0 & 1 & 4 & 3 \\
\hline 11 & Dyadyadin & $\mathrm{UBF}$ & $500-550$ & $\begin{array}{l}\text { N16 } 16^{\circ} 47^{\prime} 54^{\prime \prime} \\
\text { E122 } 22^{\circ} 23^{\prime} 32^{\prime \prime}\end{array}$ & & 3.7 & & 3 & 2 \\
\hline 12 & Nanguyaman & UBF & $500-600$ & $\begin{array}{l}\mathrm{N} 16^{\circ} 38^{\prime} 16^{\prime \prime} \\
\mathrm{E} 122^{\circ} 18^{\prime} 44^{\prime \prime}\end{array}$ & & 4.0 & & 4 & 3 \\
\hline (12) & Naguyaman $2^{\mathrm{c}}$ & UBF & $500-600$ & $\begin{array}{l}\mathrm{N} 16^{\circ} 38^{\prime} 16^{\prime \prime} \\
\mathrm{E} 122^{\circ} 18^{\prime} 44^{\prime \prime}\end{array}$ & & & & & 3 \\
\hline 13 & Puerta & MF & $1,600-1,750$ & $\begin{array}{l}\mathrm{N} 17^{\circ} 24^{\prime} \\
\mathrm{E} 122^{\circ} 02^{\prime}\end{array}$ & & & & 6 & 6 \\
\hline (13) & Puerta2 & MF & $1,600-1,750$ & $\begin{array}{l}\mathrm{N} 17^{\circ} 24^{\prime} \\
\mathrm{E} 122^{\circ} 02^{\prime}\end{array}$ & & & & 8 & 8 \\
\hline 14 & Dipalayag & MF & $950-1,160$ & $\begin{array}{l}\text { N16 } 56^{\circ} 56^{\prime} 55^{\prime \prime} \\
\text { E122 } 127^{\prime} 04^{\prime \prime}\end{array}$ & & 1.5 & & 4 & 4 \\
\hline
\end{tabular}


Table 6 continued

\begin{tabular}{|c|c|c|c|c|c|c|c|c|c|}
\hline \multirow[t]{2}{*}{ Code $^{a}$} & \multirow[t]{2}{*}{ Locality } & \multirow{2}{*}{$\begin{array}{l}\text { Forest } \\
\text { type }\end{array}$} & \multirow[t]{2}{*}{ Elevation $^{b}$} & \multirow[t]{2}{*}{ Co-ordinates } & \multirow{2}{*}{$\begin{array}{l}\text { Trees } \\
\text { Plot } \\
\text { area } \\
\text { (ha) }\end{array}$} & \multicolumn{2}{|l|}{ Birds } & \multicolumn{2}{|c|}{ Birds/bats } \\
\hline & & & & & & $\begin{array}{l}\text { Transect } \\
\text { length } \\
(\mathrm{km})\end{array}$ & $\begin{array}{l}\text { No of } \\
\text { point } \\
\text { counts }\end{array}$ & $\begin{array}{l}\text { Mist } \\
\text { net } \\
\text { days }\end{array}$ & $\begin{array}{l}\text { Mist } \\
\text { net } \\
\text { nights }\end{array}$ \\
\hline 15 & Pangal & $\mathrm{MF}$ & $500-900$ & $\begin{array}{l}\text { N1 } 6^{\circ} 50^{\prime} 34^{\prime \prime} \\
\text { E122 } \\
\\
14^{\prime} 36^{\prime \prime}\end{array}$ & & 2.5 & 2 & 6 & 6 \\
\hline 16 & Dimasalansan & MGF & 0 & $\begin{array}{l}\mathrm{N} 17^{\circ} 17^{\prime} 15^{\prime \prime} \\
\mathrm{E} 122^{\circ} 23^{\prime} 44^{\prime \prime}\end{array}$ & & & 11 & 5 & 4 \\
\hline
\end{tabular}

$L D F$ lowland dipterocarp forest, $U B F$ ultrabasic forest, $M F$ montane forest and $M G F$ mangrove forest

${ }^{a}$ Codes refer to localities in Fig. 1, codes within brackets indicate replicated surveys; ${ }^{b}$ meters above sea-level; ${ }^{\mathrm{c}}$ bats only

\section{References}

2008 IUCN red list of threatened species (2008) IUCN, Gland. http://www.iucnredlist.org. Downloaded 3 Mar 2008

Andal ES, Shoji A, Yumul GP Jr (2005) Complete mantle section of a slow-spreading ridge-derived ophiolite: an example from the Isabela ophiolite in the Philippines. Island Arc 14(3):272-294

Ashton PS (2003) Floristic zonation of tree communities on wet tropical mountains revisited. Perspectives in Plant Ecology. Evol Syst 6(1-2):87-104

Balmford A, Long A (1995) Across country analyses of biodiversity congruence and current conservation effort in the tropics. Conserv Biol 9(6):1539-1547

Bonn A, Rodrigues ASL, Gaston KJ (2002) Threatened and endemic species: are they good indicators of patterns of biodiversity on a national scale. Ecol Lett 5:733-741

Brooks TM, Stuart LP, Kapos V, Ravilious C (1999) Threat from deforestation to montane and lowland birds and mammals in insular South-east Asia. J Anim Ecol 68(6):1061-1078

Brooks TM, Mittermeier RA, Mittermeier CG, da Fonseca GAB, Rylands AB, Konstant WR, Flick P, Pilgrim J, Oldfield S, Magin G, Hilton-Taylor C (2002) Habitat loss and extinction in the hotspots of biodiversity. Conserv Biol 16(4):909-923

Caro TN, O'Doherty G (1999) On the use of surrogate species in conservation biology. Conserv Biol 13(4):805-814

Carranza EJM, Mangaoang JC, Hale M (1999) Application of mineral exploration models and GIS to generate mineral potential maps as input for optimum land-use planning in the Philippines. Nat Resour Res 8(2):165-173

Chao A, Chazdon RL, Colwell RK, Shen T-J (2005) A new statistical approach for assessing similarity of species composition with incidence and abundance data. Ecol Lett 8(2):148-159

Co LL, Tan BC (1992) Botanical exploration in Palanan wilderness, Isabela Province, the Philippines: first report. Flora Males Bull 11(1):49-53

Co LL, Lagunzad DA, LaFrankie JV, Bartolome NA, Molina JE, Yap SL, Garcia HG, Bautista JP, Gumpal EC, Arano RR, Davies SJ (2004) Palanan forest dynamic plot, Philippines. In: Losos EC, Leigh EG Jr (eds) Tropical forest diversity and dynamism: findings form a large-scale plot network. The University of Chicago Press, Chicago, pp 574-584

Collins NM, Sayer JA, Whitmore TC (1991) The conservation atlas of tropical forests. IUCN, Gland

Colwell RK (2005) EstimateS v 8.0. Available at http://viceroy.eeb.uconn.edu/estimates

DENR (Department of Environment and Natural Resources) (1992) NIPAS implementing rules and regulations. Department Administrative Order No 25. DENR, Manila

Diaz-Frances E, Soberon J (2005) Statistical estimation and model selection of species-accumulation functions. Conserv Biol 19(2):569-573

ESSC (Environmental Science for Social Change Inc) (1999) Decline of the Philippine forest. Bookmark, Makati City

Fleishman E, Thomson JR, Mac Nally R, Murphy DD, Fay JP (2005) Using indicator species to predict species richness of multiple taxonomic groups. Conserv Biol 19(4):1125-1137 
Fortus JF, Garcia HG (2002a) Floristic study of ultrabasic forest at Northern part [Diguides] of Northern Sierra Madre Natural Park. Technical report Northern Sierra Madre Natural Park-Conservation Project, Cabagan

Fortus JF, Garcia HG (2002b) Floristic study of ultrabasic forest at Southern part [Divinisa] of Northern Sierra Madre Natural Park. Technical report, Northern Sierra Madre Natural Park-Conservation Project, Cabagan

Freitag S, van Jaarsveld AS (1997) Relative occupancy, endemism, taxonomic distinctiveness and vulnerability: prioritizing regional conservation actions. Biodivers Conserv 6:211-232

Garcia HG (2002a) Floristic study of lowland dipterocarp forest at western part [Apaya] of Northern Sierra Madre Natural Park. Technical report, Northern Sierra Madre Natural Park-Conservation Project, Cabagan

Garcia HG (2002b) Floristic study of lowland dipterocarp forest at eastern part [Dimolid] of Northern Sierra Madre Natural Park. Technical report, Northern Sierra Madre Natural Park-Conservation Project, Cabagan

Garcia HG (2002c) Floristic study of mossy forest in Northern Sierra Madre Natural Park. Technical report, Northern Sierra Madre Natural Park-Conservation Project, Cabagan

Garcia HG (2002d) Floristic study of mangrove forest [Dimasalansan] in Northern Sierra Madre Natural Park. Technical report, Northern Sierra Madre Natural Park-Conservation Project, Cabagan

Gaston KJ (1992) Regional numbers of insect and plant species. Funct Ecol 6:243-247

Gaston KJ (2000) Global patterns in biodiversity. Nature 405:220-227

Heaney LR (2001) Small mammal diversity along elevational gradients in the Philippines: an assessment of patterns and hypotheses. Glob Ecol Biogeogr 10(1):15-39

Heaney LR, Balete DS, Dolar I, Alcala AC, Dans A, Gonzales PC, Ingle NR, Lepiten M, Oliver WLR, Ong PS, Rickart EA, Tabaranza, BR Jr, Utzurrum RCB (1998) A synopsis of the mammalian fauna of the Philippine islands. Fieldiana Zool 88:1-61

Heino J (2010) Are indicator groups and cross-taxon congruence useful for predicting biodiversity in aquatic ecosystems? Ecol Indic 10:112-117

Hess GR, Bartel RA, Leidner AK, Rosenfeld KM, Rubino MJ, Snider SB, Ricketts TH (2006) Effectiveness of biodiversity indicators varies with extent, grain, and region. Biol Conserv 132:448-457

Hortal J, Borges PAV, Gaspar C (2006) Evaluating the performance of species richness estimators: sensitivity to sample grain size. J Anim Ecol 75:274-287

Howard PC, Viskanic P, Davenport TRB, Kigenyi FW, Baltzer M, Dickinson CJ, Lwanga JS, Matthews RA, Balmford A (1998) Complementarity and the use of indicator groups for reserve selection in Uganda. Nature 394:472-475

Ingle NR, Heaney LR (1992) A key to the bats of the Philippine Islands. Fieldiana Zoology New Series No. 69, Field Museum of Natural History, Chicago, USA

Kennedy RS, Gonzales PC, Dickinson EC, Miranda HC Jr, Fisher TH (2000) A guide to the birds of the Philippines. Oxford University Press, Oxford

Kerr JT (1997) Species richness, endemism, and the choice of areas for conservation. Conserv Biol 11(5):1094-1100

Kissling WD, Field R, Böhning-Gaese K (2008) Spatial patterns of woody plant and bird diversity: functional relationships or environmental effects? Glob Ecol Biogeogr 17(3):327-339

Koellner T, Hersperger AM, Wohlgemut T (2004) Rarefaction method for assessing plant species diversity on a regional scale. Ecography 27:532-544

Lamoreux JF, Morrison JC, Ricketts TH, Olson DM, Dinerstein E, McKnight MW, Shugart HH (2006) Global tests of biodiversity concordance and the importance of endemism. Nature 440:212-214

Langenberger G, Martin K, Sauerborn J (2006) Vascular plant species inventory of a Philippine lowland rain forest and its conservation value. Biodivers Conserv 15(4):1271-1301

Lawton JH, Bignell DE, Bolton B, Bloemers GF, Eggleton P, Hammond PM, Hodda M, Holt RD, Larsen TB, Mawdsley NA, Stork NE, Srivastava DS, Watt AD (1998) Biodiversity inventories, indicator taxa and effects of habitat modification in tropical forest. Nature 391:72-76

Lindenmayer DB (1999) Future directions for biodiversity conservation in managed forests: indicator species, impact studies and monitoring programs. For Ecol Manag 115(2-3):277-287

Lindenmayer DB, Manning AD, Smith PL, Possingham HP, Fischer J, Oliver I, McCarthy MA (2002) The focal-species approach and landscape restoration: a critique. Conserv Biol 16:338-345

Lund MP, Rahbek C (2002) Cross-taxon congruence in complementarity and conservation of temperate biodiversity. Anim Conserv 5(2):163-171

Mac Nally R, Bennett AF, Brown GW, Lumsden LF, Yen A, Hinkley S, Lillywhite P, Ward D (2002) How well do ecosystem-based planning units represent different components of biodiversity? Ecol Appl 12(3):900-912 
Magurran AE (2004) Measuring biological diversity. Blackwell, Oxford

Mallari NAD, Jensen A (1993) Biological diversity in Northern Sierra Madre, Philippines: its implication for conservation and management. Asia Life Sci 2(2):101-112

Mallari NAD, Tabaranza BR Jr, Crosby MJ (2001) Key conservation sites in the Philippines. Bookmark, Manila

Margules CR, Pressey RL (2000) Systematic conservation planning. Nature 405:243-253

Mittermeier RA, Myers N, Thomsen JB, da Fonseca GAB (1998) Biodiversity hotpots and major tropical wilderness areas: approaches to setting conservation priorities. Conserv Biol 12(3):516-520

Moore JL, Balmford A, Brooks T, Burgess ND, Hansen LA, Rahbek C, Williams PH (2003) Performance of sub-Saharan vertebrates as indicator groups for identifying priority areas for conservation. Conserv Biol 17(1):207-218

Myers N, Mittermeier RA, Mittermeier CG, da Fonseca GAB, Kent J (2000) Biodiversity hotspots for conservation priorities. Nature 403:853-858

NAMRIA (National Mapping and Resource Information Authority) (1995) Topographic maps 1:250,000 sheets 2506 and 2508. NAMRIA, Manila

Negi HR, Gadgil M (2002) Cross-taxon surrogacy of biodiversity in the Indian Garhwal. Himal Biol Conserv 105:143-155

NORDECO, DENR (1998) Technical report, Integrating conservation and development in protected area management in the Northern Sierra Madre Natural Park, the Philippines. NORDECO and DENR, Manila

Noss RF (1990) Indicators for monitoring biodiversity: a hierarchical approach. Conserv Biol 4(4):355-364

O'Hara RB (2005) Species richness estimators: how many species can dance on the head of a pin? J Anim Ecol 74:375-386

Ong PS, Afuang LA, Rosell-Ambal RG (eds) (2002) Philippine biodiversity conservation priorities: a second iteration of the national biodiversity strategy and action plan. DENR, CI, UP Diliman, FPE, Manila

PAGASA (Philippine Atmospheric, Geophysical and Astronomical Services Administration) (2005) Monthly minimum, maximum and rainfall data from weather stations Tuguegarao and Casiguran 1975-2004. PAGASA, Manila

Part T, Soderstrom B (1999) Conservation value of semi-natural pastures in Sweden: contrasting botanical and avian measures. Conserv Biol 13(4):755-765

Pearson DL, Cassola F (1992) World-wide species richness patterns of tiger beetles (Coleoptera: cicindelidae): indicator taxon for biodiversity and conservation studies. Conserv Biol 6(3):376-391

Petersen FT, Meier R (2003) Testing species-richness estimation methods on single-sample collection data using the Danish Diptera. Biodivers Conserv 12:667-686

Posa MRC, Sodhi NS (2006) Effects of anthropogenic land use on forest birds and butterflies in Subic Bay, Philippines. Biol Conserv 129:256-270

Posa MRC, Diesmos AC, Sodhi NS, Brooks TM (2008) Hope for threatened tropical biodiversity: lessons from the Philippines. Bioscience 58(3):231-240

Poulsen MK (1995) The threatened and near-threatened birds of Luzon, Philippines, and the role of the Sierra Madre mountains in their conservation. Bird Conserv Int 5:79-116

Poulsen MK, Lambert FR (2000) Altitudinal distribution and habitat preferences of forest birds on Halmahera and Buru, Indonesia: implications for conservation of Moluccan avifaunas. Ibis 142(4):566-586

Prendergast JR, Eversham BC (1997) Species richness covariance in higher taxa: empirical tests of the biodiversity indicator concept. Ecography 20(2):210-216

Prendergast JR, Quinn RM, Lawton JH, Eversham BC, Gibbons DW (1993) Rare species, the coincidence of diversity hotspots and conservation strategies. Nature 365:335-337

Proctor J (2003) Vegetation and soil and plant chemistry on ultramafic rocks in the tropical Far East. Perspectives in Plant Ecology. Evol Syst 6(1/2):105-124

Reyers B, van Jaarsveld AS, Krüger M (2000) Complementarity as a biodiversity indicator strategy. Proc R Soc Lond B 267:505-513

Ricketts TH, Dinerstein E, Olson DO, Loucks C (1999) Who's where in North America? Patterns of species richness and the utility of indicator taxa for conservation. Bioscience 49:369-381

Rodrigues ASL, Brooks TM (2007) Shortcuts for biodiversity conservation planning: the effectiveness of surrogates. Annu Rev Ecol Evol Syst 38:713-737

RP (Republic of the Philippines) (1991) National Integrated Protected Area System (NIPAS) Act. Republic of the Philippines, Manila

RP (Republic of the Philippines) (2004) National policy agenda on revitalizing mining in the Philippines Presidential Executive Order No. 270. Republic of the Philippines, Manila 
Sheldon FH, Lim HC, Nais J, Lakim M, Majuakim J, Lo A, Schilthuizen M, Hosner PA, Moyle RG (2009) Observations on the ecology, distribution and biogeography of forest birds in Sabah, Malaysia. Raffles Bull Zool 57(2):577-586

Sodhi NS, Koh LP, Brook BW, Ng PKL (2004) Southeast Asian biodiversity: an impending disaster. Trends Ecol Evol 19(12):654-660

Sodhi NS, Posa MRC, Lee TM, Bickford D, Koh LP, Brook BW (2010) The state and conservation of Southeast Asian biodiversity. Biodivers Conserv 19:317-328

Stattersfield AJ, Crosby MJ, Long AJ, Wege DC (1998) Endemic bird areas of the world, priorities for biodiversity conservation. Birdlife International, Cambridge

Su JC, Debinski DM, Jakubauskas ME, Kindscher K (2004) Beyond species richness: community similarity as a measure of cross-taxon congruence for coarse-filter conservation. Conserv Biol 18(1):167-173

Theobald DM, Hobbs NT, Bearly T, Zack JA, Shenk T, Riebsame WE (2000) Incorporating biological information in local land-use decision making: designing a system for conservation planning. Landsc Ecol 15(1):35-45

Thiollay J (2002) Bird diversity and selection of protected areas in a large neotropical forest tract. Biodivers Conserv 11:1377-1395

Van Gemerden BS, Etienen RS, Olff H, Hommel PWFM, Van Langevelde F (2005) Reconciling methodologically different biodiversity assessments. Ecol Appl 15(5):1747-1760

Vane-Wright RI, Humphries CJ, Williams PH (1991) What to protect?-Systematics and the agony of choice. Biol Conserv 55:235-254

Walther BA, Moore JL (2005) The concepts of bias, precision and accuracy, and their use in testing the performance of species richness estimators, with a literature review of estimator performance. Ecography 28:815-829

Williams P, Gibbons D, Margules C, Rebelo A, Humphries C, Pressey R (1996) A comparison of richness hotpots, rarity hotspots, and complementary areas for conserving diversity of British birds. Conserv Biol 10(1):155-174

Wilson EO (2000) A global biodiversity map. Science 289(5488):2279 